\title{
KADERISASI NASEHAT (NARAPIDANA SEHAT) DI LAPAS NARKOTIKA KELAS III SAMARINDA
}

\author{
Nur Fithriyanti Imamah ${ }^{1}$, Marjan Wahyuni ${ }^{1}$ \\ ${ }^{1}$ Universitas Muhammadiyah Kalimantan Timur, Samarinda, Indonesia \\ *fithriimamah@gmail.com
}

\begin{abstract}
Abstrak: Lembaga Pemasyarakatan (Lapas) merupakan tempat pembinaan narapidana atau warga binaan pemasyarakatan di Indonesia. Lapas Narkotika Kelas III Samarinda memiliki jumlah hunian yang melebihi kapasitas, sehingga memungkinkan untuk terjadinya beberapa masalah kesehatan pada penghuni. Gangguan pada lingkungan berpotensi untuk memberikan gangguan kesehatan. Data dari Direktorat Jendral Pemasyarakatan (Ditjen PAS) Kementrian Hukum dan HAM menunjukkan terdapat sebanyak 6 kasus HIV, 3 kasus TB, dan 215 masalah kesehatan lain yang terjadi pada warga binaan Lapas Narkotika Kelas III Samarinda. Studi pendahuluan di Lapas Narkotika Kelas III Samarinda menunjukkan bahwa seringkali terjadi keadaan gawat darurat pada warga binaan, seperti pingsan, maupun sesak nafas yang terjadi di saat paramedis tidak berada di tempat. Padatnya hunian dan lingkungan yang kurang sehat menjadi faktor penyebab terjadinya masalah kesehatan lain seperti penyakit menular. Pengabdian masyarakat ini bertujuan untuk membentuk kader narapidana sehat yang terlatih untuk menjaga kesehatan diri dan lingkungan sekitar. Metode yang digunakan dalam pengabdian ini adalah pengembangan komunitas melalui program penyuluhan dan pelatihan. Subjek sebagai sasaran dalam pengabdian ini adalah 40 orang narapidana sebagai calon kader terpilih. Hasil pengabdian menunjukkan terdapat peningkatan pengetahuan kader sesudah diberikan pelatihan. Pengetahuan terkait kebersihan diri $(P 0.028)$ dan kebersihan lingkungan $(P 0.044)$ mengalami peningkatan yang signifikan. Namun demikian, kemampuan kader dalam menolong warga binaan pemasyarakatan dinilai masih rendah sehingga perlu diadakan pengabdian masyarakat lanjutan untuk melatih kemampuan kader. Kegiatan pengabdian masyarakat dinilai efektif untuk membentuk kader narapidana terlatih dalam bidang kesehatan.
\end{abstract}

Kata Kunci: narapidana, kesehatan, lembaga pemasyakarakan (lapas)

\begin{abstract}
Correctional Institution (Lapas) is an inmate or community correctional development place in Indonesia. Narcotic Correctional Institution Class III Samarinda has an over capacity that possibly cause the health problems for its residents. Environmental disturbance has a big potential to cause the health problem. The data from Direktorat Jendral Pemasyarakatan (Ditjen PAS) Ministry of Law and Human Right, showed that there were 6 HIV cases, 3 Tuberculosis cases, and 215 other health problems on the site. Pre-eliminary study showed that some of emergency condition happened in inmate, such as collapse, asthma when the paramedic is not in the place. High density population and unsanitary environment could be a factor for contagious infectious diseases. This community service program aims to form the trained health inmate cadre to care their self-health and environment. A method used in this activity was forming the cadre and training for the inmate cadre candidates. The number of cadre who has been trained were 40 persons. The result showed that there is an increase in cadre's knowledge after training. The knowledge about self-health $(P 0.028)$ and health environment $(P 0.044)$ significantly increase after the training program. However, the ability of cadres in helping the other inmate was still low and need further community service to increase the skills. This program was effective to create trained inmate especially for a health sector.
\end{abstract}

Keywords: inmate, health, correctional institution

\section{Pendahuluan}

Lembaga Pemasyarakatan (LAPAS) atau biasa disebut dengan rumah tahanan (rutan) merupakan wadah untuk melaksanakan pembinaan narapidana atau warga binaan 
pemasyarakatan di Indonesia agar menjadi lebih baik (Kementerian Hukum dan Hak Asasi Manusia RI, 2006). LAPAS bertujuan untuk membentuk Warga Binaan Pemasyarakatan agar sadar akan kesalahannya, berupaya memperbaiki diri, tidak mengulang di masa yang akan datang dan bisa kembali menjadi masyarakat sebagai manusia yang utuh dan berperan aktif serta hidup secara wajar dan bertanggung jawab sebagai warga negara. Upaya peningkatan kesehatan dan keselamatan warga binaan pemasyarakatan berarti membuktikan bahwa di LAPAS perlu memperhatikan kesehatan narapidana secara menyeluruh, tidak hanya berfokus pada masalah sosial. Peningkatan jumlah penghuni LAPAS seringkali menimbulkan masalah over kapasitas yang terjadi hampir di seluruh wilayah Indonesia. Kepadatan penghuni secara tidak langsung berdampak pada masalah kesehatan bagi warga binaan (Fachrezi \& Wibowo, 2020; Humananda et al., 2014).

Sumber daya manusia yang terdapat pada Lapas Narkotika Kelas III Samarinda terdiri dari 42 orang pria dan 8 orang wanita yang terdiri dari struktural sebanyak 5 orang, dukungan teknis keuangan, kepegawaian, perlengkapan, umum, dan TU sebanyak 4 orang, satuan pengamanan sebanyak 26 orang, pembina PAS, pelayanan/perawatan, pemeliharaan, dan pengelolaan sebanyak 11 orang (Direktorat Jendral Pemasyarakatan (Ditjen PAS), 2017a). Terdapat sebanyak 1.347 orang yang terdiri dari 1.191 tahanan dewasa laki-laki, dan 156 tahanan dewasa perempuan yang berada di Lapas Narkotika Kelas III Samarinda. Lapas Narkotika Kelas III Samarinda memiliki jumlah hunian yang melebihi kapasitas, over kapasitas sebanyak 283 orang, sehingga memungkinkan untuk terjadinya beberapa masalah kesehatan pada penghuni (Direktorat Jendral Pemasyarakatan (Ditjen PAS), 2018).

Data dari Direktorat Jendral Pemasyarakatan (Ditjen PAS) Kementrian Hukum dan HAM pada Desember tahun 2017 menunjukkan terdapat sebanyak 6 kasus HIV , 3 kasus TB, dan 215 masalah kesehatan lain yang terjadi pada warga binaan Lapas Narkotika Kelas III Samarinda (Direktorat Jendral Pemasyarakatan (Ditjen PAS), 2017b). Hasil wawancara dengan petugas kesehatan di Lapas Narkotika Kelas III Samarinda menunjukkan bahwa seringkali terjadi keadaan gawat darurat pada warga binaan, seperti pingsan, maupun sesak nafas yang terjadi pada saat paramedis tidak berada di tempat. Beberapa masalah kesehatan lain yang diderita oleh Lapas Narkotika Kelas III Samarinda adalah mudahnya penularan penyakit menular diakibatkan oleh padatnya hunian dan beberapa penyakit yang disebabkan oleh rendahnya kebersihan diri, seperti: skabies, dermatitis, dan diare.

Untuk memperoleh derajat kesehatan yang optimal, diperlukan kesadaran, kemauan, dan kemampuan untuk hidup sehat bagi setiap penduduk (Soejoeti, 2005). Kesehatan merupakan kedinamisan antara kesempurnaan jasmani, mental, dan sosial, yang memungkinkan seseorang mencapai derajat kesehatan yang optimal secara ekonomi dan sosial (Depkes, 1992). Masalah kesehatan dapat ditandai dengan keberadaan penyakit yang dapat dilihat dari gangguan pada fisik, mental, dan spiritual. Gangguan pada lingkungan juga berpotensi untuk memberikan gangguan kesehatan.

Skabies merupakan penyakit yang disebabkan ektoparasit (Heukelbach \& Feldmeier, 2006). Skabies merupakan penyakit menular yang dapat menyebar cepat dalam jangka waktu yang relatif lama dan biasa terjadi pada hunian yang padat seperti pada pondok pesantren, 
panti asuhan, atau lembaga pemasyarakatan (Badri, 2007). Skabies memiliki persentase penderita lebih besar $(78,7 \%)$ pada komunitas padat hunian dengan kebersihan yang buruk (Sungkar, 2000). Penularan skabies bisa terjadi akibat kontak langsung ataupun dari fomite. Beberapa faktor yang menyebabkan penularan skabies antara lain: kebiasaan tidur, berbagi baju, handuk, praktek kebersihan yang tidak benar, dan bepergian ke tempat berisiko (Timmreck, 2005).

Pertolongan pertama diberikan pada kondisi yang membahayakan jiwa, dan mengancam kehidupan. Pertolongan pertama bertujuan untuk mempertahankan penderita tetap hidup, stabil, mengurangi rasa nyeri, ketidaknyamanan dan rasa cemas. Beberapa keadaan yang membahayakan hidup antara lain henti denyut jantung dan pernafasan, tersedak, tenggelam, tersengat aliran listrik, dan keracunan (Kusumaningrum et al., 2018; Sumardino \& Widodo, 2014).

Upaya peningkatan kesehatan pada warga binaan tertera pada Peraturan Pemerintah Nomor 32 Tahun 1999 tentang Syarat dan Tata Cara Pelaksanaan Hak Warga Binaan Pemasyarakatan, Pasal 14 dan Pasal 20 ayat (1) bagian ke empat mengenai pelayanan kesehatan dan makanan dinyatakan bahwa: "Setiap Narapidana dan Anak Didik Pemasyarakatan berhak memperoleh pelayanan kesehatan yang layak. Pada setiap lembaga pemasyarakatan disediakan poliklinik beserta fasilitasnya dan disediakan sekurang-kurangnya seorang dokter dan seorang tenaga kesehatan lainnya." Sementara Pasal 20 ayat (1) menyatakan "Narapidana dan Anak Didik Pemasyarakatan yang sakit, hamil atau menyusui berhak mendapatkanmakanan tambahan sesuai dengan petunjuk dokter" (Pemerintah Republik Indonesia, 1999)

Berbagai upaya kesehatan dilaksanakan melalui pencegahan, penyembuhan dan meningkatkan pelayanan kesehatan diantaranya pemberantasan penyakit menular, peningkatan gizi narapidana, kesehatan lingkungan, persediaan obat-obatan, penyuluhan kesehatan dan peralatan medis yang memadai. Hal tersebut bertujuan untuk menunjang proses perawatan dan pelayanan kesehatan, yang dapat diselenggarakan secara berdaya guna, berhasil guna, tertib dan bertanggung jawab, sehingga kesehatan narapidana dan tahanan di Lapas/Rutan semakin meningkat. Upaya memenuhi hak-hak narapidana di atas pada implementasianya masih belum optimal. Hal ini karena terdapat hambatan-hambatan yang muncul, seperti kelayakan lembaga pemasyarakatan di daerah, sarana dan prasarana, kurangnya personil, hingga kendala terkait over kapasitas penghuni lapas. Pemerintah juga memiliki peran yang sangat penting didalam melakukan pemenuhan pelayanan kesehatan bagi narapidana, hal ini sangat terkait dengan fungsi pemerintah sebagai alat untuk selalu meningkatkan kesehatan masyarakatnya termasuk narapidana (Fachrezi \& Wibowo, 2020).

Pengabdian masyarakat ini bertujuan untuk membentuk kader narapidana sehat yang terlatih untuk menjaga kesehatan diri dan lingkungan sekitar. Manfaat yang didapatkan dari kegiatan pengabdian masyarakat ini antara lain; menjadi wadah dalam pengaplikasian ilmu pengetahuan yang telah didapatkan, membantu mengatasi permasalahan keterbatasan sumber daya dalam hal kesehatan, dan meningkatkan pengetahuan dan kemampuan dalam penanganan masalah kesehatan yang terjadi di Lapas Narkotika Kelas III Samarinda. 


\section{Metode}

Pada pengabdian masyarakat ini, pendekatan yang digunakan adalah pengembangan komunitas, penyuluhan dan pelatihan. Pengembangan komunitas atau pengembangan masyarakat dilaksanakan bersama-sama oleh anggota komunitas untuk mencari solusi dari permasalahan yang dihadapi bersama. Fokus pengembangan komunitas adalah pendampingan penyelesaian masalah yang dihadapi oleh komunitas dengan tujuan menghasilkan keberdayaan masyarakat. Dalam pengembangan komunitas, selain berfokus pada pembangunan fisik, aspekaspek sosial, politik, ekonomi, dan budaya, juga perlu untuk dikembangkan. Pemberdayaan dilakukan dengan membantu komunitas dengan sumber daya, kesempatan, keahlian, dan pengetahuan agar komunitas dapat menentukan masa depan warganya kemudian (Phillips \& Pittman, 2008). Pengembangan komunitas dilakukan dengan kegiatan pembentukan kader kesehatan. Alur pengabdian ini dapat dilihat pada gambar 1.

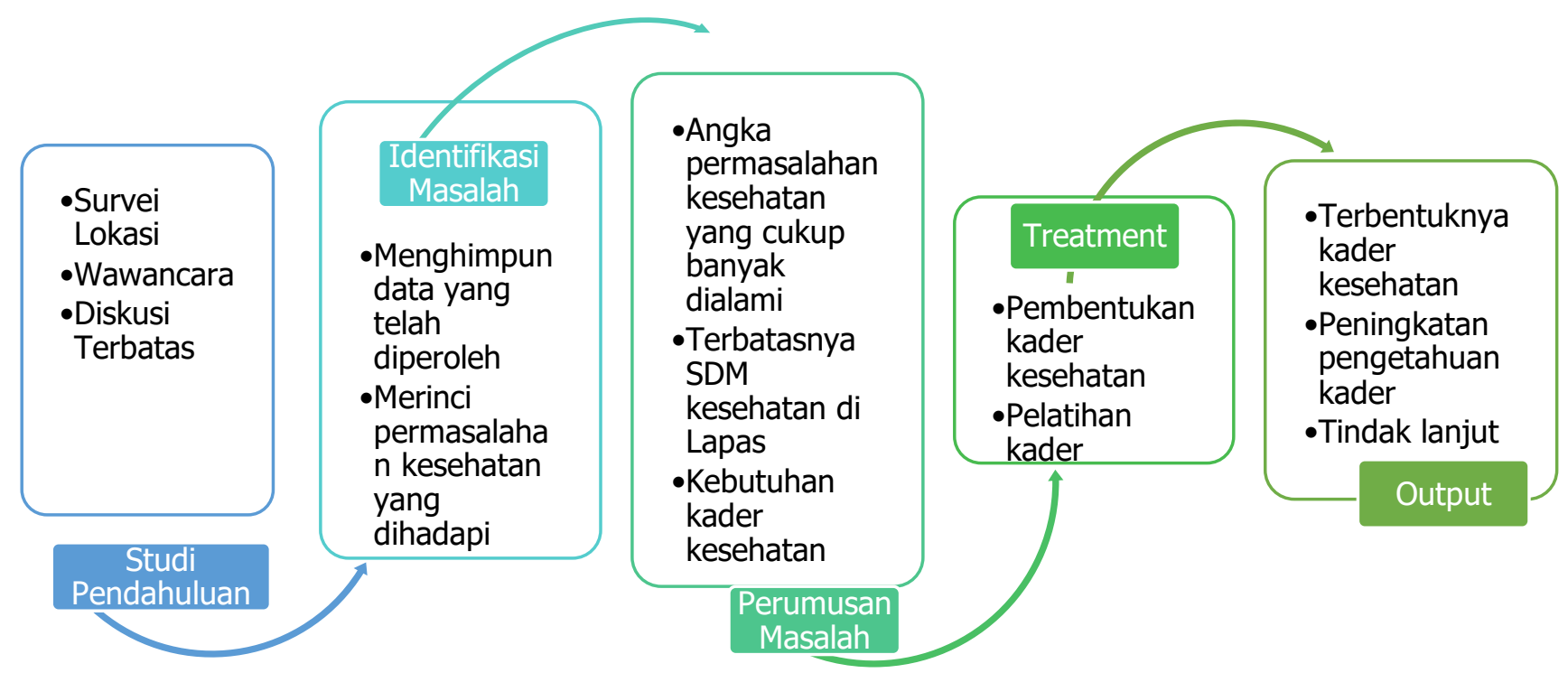

Gambar 1. Diagram Alur Pengabdian Masyarakat

Salah satu prinsip keberhasilan kegiatan pembangunan komunitas adalah komunitas berupaya membantu diri sendiri dan bertanggung jawab atas dirinya sendiri (Self help and self responsibility) karena komunitas yang paling faham apa yang diperlukan dan di rubah dalam komunitas. Beberapa prinsip pengembangan komunitas antara lain membangun kepercayaan (Trust building), memahami kondisi yang didampingi, didapatkannya kader lokal yang berpotensi, penyadaran untuk perubahan, konsensus bersama, dan kekuatan pengambilan keputusan (Phillips \& Pittman, 2008).

Pada tahap pembentukan kader, tahap pertama yang dilakukan adalah sosialisasi mengenai kader nasehat. Di tahap ini, para calon kader diberitahu mengenai latar belakang dibutuhkannya kader narapidana sehat (nasehat), fungsi dan tujuan kader dalam membantu menyelesaikan masalah kesehatan di Lapas. Tahap kedua adalah pembentukan kader nasehat. 
Kader terpilih dipilih oleh tenaga paramedis Lapas dengan melihat potensi masing-masing kader dan pengalaman dalam keaktifan mengikuti kegiatan selama di Lapas. Kader terpilih mampu berkomunikasi aktif dan mempunyai kesempatan yang cukup untuk meyebarluaskan informasi di lingkungan Lapas Narkotika Kelas III Samarinda.

Kegiatan lain setelah pembentukan kader adalah penyuluhan dan pelatihan kader nasehat mengenai dasar ilmu terkait kesehatan sesuai dengan masalah kesehatan di Lapas. Pendidikan kesehatan dengan metode penyuluhan bertujuan untuk meningkatkan pengetahuan seseorang (Sofiana et al., 2018). Pada kesempatan ini, kader diberikan penyuluhan mengenai pengetahuan mengenai kesehatan perorangan dan lingkungan, pertolongan pertama pada penyakit yang sering ditemui di Lapas, dan sanitasi dasar. Pelatihan berupa praktik diharapkan dapat meningkatkan kemampuan kader dalam melakukan tindakan yang tepat dalam mengaplikasikan pengetahuan yang didapat dari penyuluhan. Kuesioner evaluasi digunakan untuk mengukur pengetahuan peserta sebelum dan sesudah kegiatan. Selanjutnya, data dianalisis untuk melihat perbedaan tingkat pengetahuan para kader sebelum dan sesudah kegiatan. Nilai praktik didapat pada saat praktik di masa evaluasi pelatihan.

\section{Hasil dan Pembahasan}

Jumlah kader terpilih ada sejumlah 40 orang yang tercatat aktif mengikuti kegiatan secara lengkap mulai dari pelatihan pertama hingga akhir. Kader terpilih dipilih berdasarkan kemungkinan lama tinggal di Lapas Narkotika Samarinda. Kader yang terpilih adalah kader yang masa tinggalnya masih lama ( $>2$ tahun) dan berasal dari perwakilan setiap Villa /Blok yang ada di Lapas Narkotika Samarinda. Perwakilan dari warga binaan pemasyarakatan perempuan sejumlah 5 orang dan, 35 orang dari perwakilan warga binaan pemasyarakatan laki-laki. Pemilihan kader berdasarkan Vila/Blok yang terdapat di Lapas Narkotika Samarinda bertujuan untuk memeratakan layanan kesehatan warga binaan pemasyarakatan Lapas. Kader-kader yang telah diresmikan ini diharapkan dapat menjadi perpanjangan tangan dari tenaga kesehatan Lapas mengingat minimnya jumlah tenaga kesehatan yang tersedia hingga saat ini.

Kegiatan pengabdian masyarakat ini berupa sosialisasi peran kader, pembentukan kader, dan pelatihan kader. Kegiatan sosialisasi hanya dilakukan secara umum, belum mendalam terkait fungsi kader dalam organisasi tersebut. Keterbatasan waktu menjadi kendala terbesar dalam menyampaikan tugas rinci masing-masing kader di Lapas Narkotika Samarinda. Perlu adanya pengabdian lanjutan untuk meningkatkan kemampuan kader terkait peran kader sebagai kader nasehat di Lapas Samarinda.

Peresmian kader telah dilakukan bersamaan dengan pelatihan kader ke-2 terkait kebersihan diri dan lingkungan. Peresmian kader diharapkan menjadi motivasi tersendiri bagi kader Nasehat terpilih untuk meningkatkan kepercayaan diri mereka dalam membantu memberi pelayanan kesehatan sesuai dengan kapasitas ilmu yang telah didapatkan selama pelatihan. Hal yang belum terlaksana pada peresmian kader adalah pengisian formulir kesediaan dan pembentukan struktur organisasi kader Nasehat tersebut. 
Pembentukan kader lokal diharapkan dapat membantu mengenali masalah utama yang dihadapi oleh sekelompok masyarakat (Phillips \& Pittman, 2008). Pelatihan kader kesehatan telah dilakukan dengan memberikan pengetahuan terkait pertolongan pertama pada keadaan gawat darurat berupa pingsan dan asma. Pengetahuan lain yang diberikan pada kader adalah pengetahuan terkait kebersihan diri dan lingkungan mengingat rentan dan besarnya resiko penularan penyakit yang diakibatkan oleh kepadatan hunian Lapas Narkotika Samarinda.

\section{Pengetahuan Kader}

Tabel 1 menjelaskan mengenai rata-rata nilai pengetahuan kader narapidana sehat sebelum dan sesudah kegiatan.

Tabel 1. Rata-rata Pengetahuan Kader terkait Pertolongan Pertama, Kebersihan Diri, dan Kebersihan Lingkungan

\begin{tabular}{ccccc}
\hline $\begin{array}{c}\text { Materi } \\
\text { Pengetahuan }\end{array}$ & \multicolumn{2}{c}{ Pertolongan Pertama } & \multicolumn{2}{c}{ Kebersihan } \\
\cline { 2 - 5 } Nilai rata-rata & Asma & Pingsan & Kebersihan Diri & $\begin{array}{c}\text { Kebersihan } \\
\text { Lingkungan }\end{array}$ \\
\hline
\end{tabular}

Nilai rata-rata pengetahuan kader Nasehat tertinggi adalah pengetahuan mengenai kebersihan lingkungan sebesar 91.81, diikuti oleh pengetahuan asma dengan nilai rata-rata 90.5, dan kebersihan diri adalah 82.88. Nilai-nilai ini menunjukkan bahwa rata-rata pengetahuan kader terkait tiga hal tersebut sangatlah baik sebelum dan sesudah diberikan pelatihan. Hal ini bisa disebabkan bahwa kejadian asma adalah kejadian yang sering ditangani oleh kader saat menemui warga binaan pemasyarakatan mengalami hal tersebut.

Pendidikan kesehatan dapat membantu meningkatkan pengetahuan (Sofiana et al., 2018). Kebersihan diri dan kebersihan lingkungan adalah materi dasar yang mungkin sering didapatkan serta dipraktikkan berulang dalam keseharian warga binaan pemasyarakatan Lapas Narkotika Samarinda. Praktik yang berulang tersebut juga menyebabkan tingginya nilai pengetahuan kader terkait kebersihan diri dan lingkungan. Pengalaman dalam menangani kejadian asma bisa menyebabkan tingginya pengetahuan terkait pertolongan pertama pada pasien asma.

Hal berbeda terjadi pada nilai rata-rata pengetahuan kader terkait pertolongan pertama pada pasien pingsan senilai 64,75 . Nilai pengetahuan mengenai pertolongan pertama pada kejadian pingsan menjadi nilai paling rendah dibandingkan dengan pengetahuan lain. Hal ini mungkin disebabkan terkait kurangnya pengetahuan pasien dan ketidak percayaan diri dalam menolong pasien pingsan. Dari hasil wawancara dengan paramedis lapas, disampaikan bahwa sebelumnya pada saat menemukan warga binaan pemasyarakatan lain yang pingsan adalah langsung memanggil petugas kesehatan. Hal ini menjadi bagian penting yang perlu diperhatikan mengingat banyaknya kejadian pingsan yang mungkin ditemui di warga binaan pemasyarakatan Lapas Narkotika Samarinda. 


\section{Perbandingan Nilai Rata-rata Pengetahuan Sebelum dan Sesudah Pelatihan}

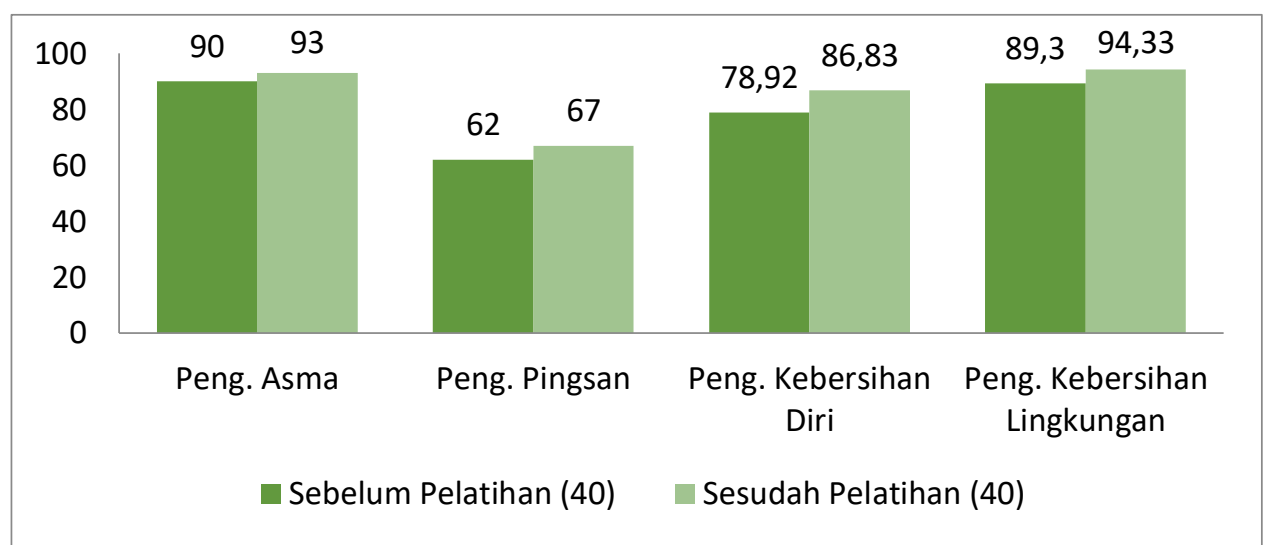

Gambar 2. Nilai Rata-rata Pengetahuan Kader terkait Pertolongan pertama, kebersihan diri, dan kebersihan lingkungan sebelum dan sesudah pelatihan

Gambar 2 menunjukkan perbedaan pengetahuan kader sebelum dan sesudah pelatihan yang dilaksanakan dalam pengabdian masyarakat. Nilai rata-rata pengetahuan kader setelah pelatihan meningkat, namun tidak terlalu tinggi. Pengetahuan terkait penanganan pasien pada keadaan pingsan menjadi bagian khusus yang perlu diperhatikan dan ditindaklanjuti mengingat pentingnya pengetahuan tersebut dalam melaksanakan pelayanan kesehatan terutama memberikan pertolongan pertama pada keadaan gawat darurat. Selanjutnya, data dianalisa lebih lanjut menggunakan uji Wilcoxon untuk melihat signifikansi perbedaan pengetahuan sebelum dan sesudah pelatihan.

Tabel 2. Pengetahuan Kader sebelum dan Sesudah Penyuluhan dan Pelatihan

\begin{tabular}{lccccc}
\hline \multicolumn{1}{c}{ Pengetahuan } & \multicolumn{2}{c}{ Pre Tes } & \multicolumn{2}{c}{ Post Tes } & \multirow{2}{*}{$\begin{array}{c}\text { P Value (Wilcoxon } \\
\text { signed rank test) }\end{array}$} \\
\cline { 2 - 5 } & Median & Range & Median & Range & \\
\hline Asma & 100 & $60-100$ & 100 & $60-100$ & 0.153 \\
Pingsan & 60 & $0-100$ & 60 & $20-100$ & 0.220 \\
Kebersihan Diri & 83.33 & $42-100$ & 82 & $57-100$ & $0.028^{*}$ \\
Kebersihan Lingkungan & 100 & $43-100$ & 100 & $43-100$ & $0.044^{*}$ \\
\hline
\end{tabular}

Tabel 2 menunjukkan bahwa terdapat perbedaan pengetahuan yang signifikan pada pengetahuan mengenai kebersihan diri dan kebersihan lingkungan sebelum dan sesudah pelatihan. Humananda et al., (2014) menyebutkan bahwa sebagian besar warga binaan LAPAS umumnya memiliki kebersihan diri yang baik, di mana masing-masing warga binaan memiliki handuk yang memenuhi syarat, dan mandi sebanyak dua kali sehari. Pihak LAPAS juga memfasilitasi untuk peralatan kebersihan diri berupa sabun, deterjen, dan lain-lain yang diberikan selama 3 bulan sekali (Humananda et al., 2014). Kebersihan lingkungan menjadi hal wajib yang harus silakukan oleh warga binaan LAPAS. Berbagai upaya telah dilakukan untuk memantau dan memelihara kesehatan lingkungan LAPAS oleh tenaga kesehatan dengan melibatkan warga binaan. Hal ini kemudian yang membantu meningkatkan pengetahuan kader mengenai kesehatan lingkungan. 


\section{Kemampuan Kader dan Praktik Pelaksanaan Hasil Pelatihan pada Kader}

Pelatihan berupa praktik hanya diberikan untuk meningkatkan kemampuan kader dalam melakukan pertolongan pertama pada kejadian gawat darurat. Evaluasi praktik hanya dinilai setelah pelaksanaan praktik. Nilai rata-rata praktik kader dalam melakukan pertolongan pertama pada keadaan gawat darurat adalah 81.16, termasuk tinggi. Hal tersebut dapat dipengaruhi oleh jeda waktu yang cukup singkat antara pendidikan kesehatan berupa penyuluhan dengan proses praktik sehingga pengetahuan dan kemampuan kader cenderung lebih tinggi.

Hasil tindak lanjut setelah kegiatan dilaksanakan, dievaluasi dengan wawancara dengan paramedis kesehatan LAPAS. Pada praktik pelaksanaannya dalam keseharian kader, masih dinilai rendah. Hal tersebut didapatkan dari tenaga pembantu yang merupakan tenaga kesehatan di Lapas Narkotika Samarinda. Terdapat kejadian gawat darurat di satu bulan terakhir yang tidak tertolong dengan baik karena masih kurangnya kepercayaan diri kader Nasehat dalam menolong pada saat keadaan gawat darurat. Hal ini menjadi evaluasi tersendiri untuk meningkatkan kemampuan dan kepercayaan diri kader dalam melakukan pertolongan.

\section{Kesimpulan}

Kegiatan pengabdian masyarakat yang telah dilaksanakan berupa sosialisasi kader, pembentukan kader, dan pelatihan kader. Kader narapidana sehat (nasehat) telah terbentuk terdiri dari narapidana terpilih sesuai potensi yang diharapkan. Pengetahuan kader masih rendah dalam memberikan pertolongan pertama untuk pasien pingsan, namun pada aspek pengetahuan lain sudah sangat baik. Perlu diadakannya pengabdian lanjutan untuk melatih kemampuan kader terkait organisasi kader kesehatan dan tugas pokok masing-masing kader. Narapidana memilik batas waktu tahanan yang berbeda satu dengan yang lainnya. Setelah terbentuk struktur organisasi yang rapi dan terperinci, diperlukan kaderisasi pada kader dengan masa tahanan yang lebih lama untuk menjaga kesinambungan kaderisasi nasehat. Peningkatan pengetahuan dapat berfokus pada materi pertolongan pertama pada keadaan gawat darurat. Peningkatan soft skill terkait kepercayaan diri juga dinilai penting untuk meningkatkan kepercayaan diri dalam melakukan fungsi kader sebagai kader kesehatan di lapas. Evaluasi kebersihan diri dan lingkungan melalui deteksi penyakit berbasis lingkungan selama periode tiga bulan sekali akan menjadi sarana untuk deteksi awal mencegah penularan penyakit berbasis lingkungan lebih lanjut yang mungkin disebabkan oleh padatnya hunian.

\section{Ucapan Terima Kasih}

Terima kasih kepada Universitas Muhammadiyah Kalimantan Timur yang telah memberikan dukungan dana dan Lapas Narkotika Kelas III Samarinda atas kerjasamanya dalam kegiatan.

\section{Referensi}

Badri, M. (2007). Hygiene perseorangan santri pondok pesantren Wali Songo Ngabar Ponorogo. Media Penelitian dan Pengembangan Kesehatan, 17(2), 20-27 
Depkes, R. (1992). UU RI No. 23 Tahun 1992 Tentang Kesehatan. Depkes RI.

Direktorat Jendral Pemasyarakatan (Ditjen PAS), K. H. H. (2017a). Data Jumlah Sumber Daya Manusia Per-UPT pada Kanwil Desember 2017

Direktorat Jendral Pemasyarakatan (Ditjen PAS), K. H. H. (2017b). Data Perawatan Per-UPT pada Kanwil Desember 2017

Direktorat Jendral Pemasyarakatan (Ditjen PAS), K. H. H. (2018). Data Jumlah Penghuni Per-UPT pada Kanwil Desember 2017

Fachrezi, F. B., \& Wibowo, P. (2020). Upaya Pemenuhan Hak Pelayanan Kesehatan Kepada Narapidana Di Lembaga Pemasyarakatan. Widya Yuridika: Jurnal Hukum, 3(2), 363-376. https://doi.org/https://doi.org/10.31328/wy.v3i2.1689

Heukelbach, J., \& Feldmeier, H. (2006). Scabies. The Lancet, 3679524), 1767-1774. https://doi.org/https://doi.org/10.1016/S0140-6736(06)68772-2

Humananda, N., Pranowowati, P., \& Siswanto, Y. (2014). Analisis permasalahan kesehatan pada narapidana di lembaga pemasyarakatan klas IIA Ambarawa. Artikel Penelitian. Ambarawa: Stikes Ngundi Waluyo.

Kementerian Hukum dan Hak Asasi Manusia RI, K. (2006). Undang-undang RI tentang Kewarganegaraan Indonesia. Jakarta, Indonesia: Kementerian Hukum dan Hak Asasi Manusia RI

Kusumaningrum, B. R., Kartika, A. W., Ulya, I., Choiriyah, M., Ningsih, D. K., \& Kartikasari, E. (2018). Pelatihan Pertolongan Pertama pada Kegawatdaruratan di Sekolah Children Centre Brawijaya Smart School Malang. International Journal of Community Service Learning, 2(4), 309-314. https://doi.org/http://dx.doi.org/10.23887/ijcsl.v2i4.14366

Pemerintah Republik Indonesia, R. (1999). Syarat dan Tata Cara Pelaksanaan Hak Warga Binaan Pemasyarakatan. Jakarta, Indonesia: Pemerintah Republik Indonesia, RI

Phillips, R., \& Pittman, R. (2008). An introduction to community development. Routledge.

Soejoeti, S. Z. (2005). Konsep sehat, sakit dan penyakit dalam konteks sosial budaya. Majalah Cermin Dunia Kedokteran, 149

Sofiana, L., Puratmadja, Y., Sari, B. S. K., Pangulu, A. H. R., \& Putri, I. H. (2018). Pengetahuan Tentang Hipertensi Melalui Metode Penyuluhan. Jurnal Pemberdayaan: Publikasi Hasil Pengabdian Kepada Masyarakat, 2(1), 171-176. https://doi.org/ https://doi.org/10.12928/jp.v2i1.443

Sumardino, S., \& Widodo, W. (2014). Kompetensi Guru UKS dalam Memberikan Pertolongan Pertama pada Kecelakaan (P3K). Interest: Jurnal IImu Kesehatan, 3(1).

Sungkar, S. (2000). Skabies. Jakarta: Yayasan Penerbit Ikatan Dokter Indonesia.

Timmreck, T. C. (2005). Epidemiologi Suatu Pengantar Edisi kedua. Jakarta (ID): EGC. 